\title{
DAMPAK PANDEMI COVID-19 TERHADAP KEGIATAN BELAJAR MENGAJAR DI MI/SD (Studi KBM Berbasis Daring Bagi Guru Dan Siswa)
}

\author{
A Risalah', W Ibad ${ }^{2}$, L Maghfiroh ${ }^{3}$, M I Azza4, S A Cahyani', Z A Ulfayati ${ }^{6}$ \\ 12 Institute University of Islamic Al Khoziny Sidoarjo, Indonesia \\ 3456 Islamic State University of Sunan Ampel, Surabaya, Indonesia
}

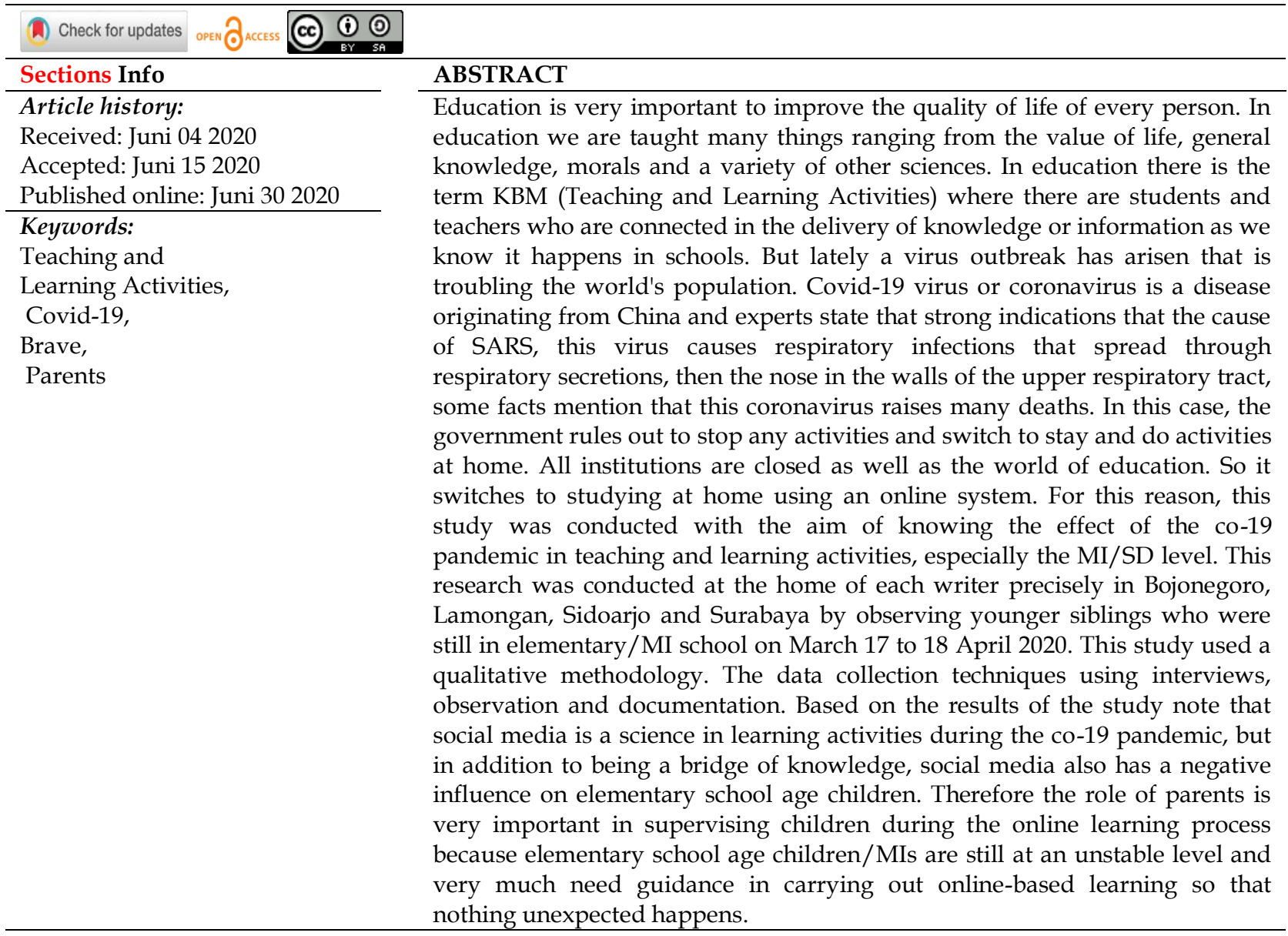

\section{INTRODUCTION}

Media sosial merupakan sebagian hasil dari kemajuan perkembangan teknologi, seiring dengan perkembangan zaman. Pada era globalisasi media sosial semakin banyak jenisnya dan berkembangnya pun sangat pesat sekali. Di era globalisasi ini banyak sekali kecanggihan pada media sosial yang menjadikan bagian yang sulit untuk dijauhkan dari kehidupan manusia apalagi dalam dunia pendidikan. Michael Haenlein mendefinisikan media sosial sebagai "sebuah kelompok aplikasi berbasis internet yang membangun di atas dasar ideologi dan teknologi Web 2.0 dan memungkinkan penciptaan dan pertukaran user-generated content" (Sindang, 2013), (Setyorini, 2020), (Khasanah, Pramudibyanto, \& Widuroyekti, 2020). Mulai dari sekolah dasar sampai dengan jenjang yang lebih tinggi (Perguruan tinggi), salah satu dari media sosial 
tersebut yaitu berupa internet. Internet adalah jaringan komputer yang ada di dunia pada saat ini, internet merupakan sebuah singkatan dari kata Interconnected Network (Yuhefizar, 2008), (Pakpahan \& Fitriani, 2020). Internet merupakan sebuah perpustakaan yang tanpa batas dalam pencakupannya. Media sosial memiliki ciri-ciri yakni partisipasi, perbincangan, dan keterbukaan (Tosepu, 2018). Dengan menggunakan media sosial yang berupa internet semua informasi ada dan dapat memudahkan peserta didik dalam mengaksesnya. Bahkan sudah hampir semua di negara maju maupun negara berkembang dapat memanfaatkan internet sebagai jendela informasi (Permana, 2018), (Firman, 2020).

Semua kejadian hampir diseluruh bumi ini sedang booming dengan adanya virus covid-19, terutama di Negara Indonesia yang saat ini sedang maraknya terserang virus covid-19. Virus covid-19 atau coronavirus adalah penyakit yang berasal dari Cina dan para ahli menyatakan bahwa indikasi kuat bahwa penyebab SARS, virus ini penyebab infeksi saluran pernapasan yang menyebar melalui sekresi pernapasan, kemudian hidung pada dinding saluran pernapasan bagian atas, beberapa fakta menyebutkan coronavirus ini menimbulkan banyak kematian, virus ini diduga mengalami mutasi sehingga bersifat semakin ganas (Aryulina, 2006). Hingga semua orang berhenti beraktifitas dan melaksanakan semua kegiatan didalam rumah. Dan tentu saja hal ini secara tidak langsung dapat mengganggu Kegiatan Belajar Mengajar di sekolah. Pelaksanaan Work from Home (WFH) (Robert J. Glass, 2006) ini di berbagai sekolah dilatar belakangi oleh meluasnya penyebaran virus corona disejumlah daerah. Hal ini juga dapat dikaitkan dengan hak pendidik dan juga peserta didik atas keselamatan belajar mengajar (Herliandry, Nurhasanah, Suban, \& Heru, 2020), (Herliandry et al., 2020).

Sebagai upaya untuk mencegah dan melindungi guru maupun siswa, beberapa pihak berwenang menetapkan kebijakan WFH untuk sementara waktu (Harususilo, 2020), (Pahan \& Fitriani, 2020). Dalam hal ini pendidik dan siswa diharuskan untuk belajar secara online dan menjalankan social distancing selama terjadinya wabah corona ini guna untuk memutus jaringan virus tersebut. Meski demikian dampak adanya WFH sangatlah terasa karena keterbiasaan kita dalam bersosial dan saling sapa menyapa antara guru dan siswa harus terbatas yang memiliki dampak positif juga negatif tersendiri bagi seorang guru dan siswa terutama dalam proses ini. Siswa dituntut untuk selalu bisa memahami pelajaran yang diberikan oleh guru dengan keterbatasan yang ada, karena sistem belajar daring yang membutuhkan sinyal sebagai media penyalur pembelajaran yang tidak sepenuhnya bisa terakses dengan baik disemua wilayah yang ada juga bisa mengganggu adanya proses kegiatan belajar mengajar (Amalina, 2021), (Ahmad Jaelani, Hamdan Fauzi, Hety Aisah, 2020), (Wiryanto, 2020).

Termasuk peserta didik pun juga diliburkan, hal ini merupakan usaha dari pemerintah guna mencegah perkembangan virus covid-19 yang penularanannya sangat cepat. Terkait dengan kejadian ini peserta didikpun tidak sekedar dliburkan akan tetapi tetap belajar dirumah. Peserta didik bisa melakukan pembelajaran secara daring dengan menggunakan internet dirumah masing masing, agar dalam kondisi pandemi covid-19 ini tidak mematahkan atau memutuskan semangat belajar mereka, karena pendidikan untuk mereka tetap menjadikan prioritas utama. Maka dari itu salah 
satunya agar tidak berhenti dalam proses pembelajaran ditengah-tengah wabah ini yaitu peserta didik melakukan pembelajaran secara online, namun bagaimana dengan pengaruh nya media sosial bagi anak SD/MI sebagai jembatan Ilmu diera pandemi covid-19?

Media sosial sebagai jembatan proses belajar bagi anak SD/MI diera pandemi covid-19 dapat dilakukan melalui pembelajaran online (Putranti, 2013), (Taseman, 2020). Dengan media pembelajaran online ini peserta didik menggunakan fasilitas internet supaya bisa berkomunikasi dan menyalurkan materi secara online dengan jarak yang jauh. Jadi penggunaan internet tidak hanya untuk bersosial media ataupun penggunaan game online akan tetapi internet juga bisa dijadikan media pembelajaran sehingga dapat menunjang pembelajaran siswa apalagi diera pandemi covid -19 ini.

Pada media sosial dapat digunakan sebagai media pembelajaran secara online melalui berbagai aplikasi yang mengacu pada pendidikan diantaranya, melalui aplikasi ruang guru, zenius, zoom meet, google classroom, google hangouts, quipper, quizizz, edmodo dan juga masih banyak aplikasi yang lainnya yang dapat bermanfaat untuk mendukung pembelajaran tetap berlangsung.

Peran orangtua sangatlah penting dalam mendampingi belajar anak ketika di rumah yang saat ini pembelajaran berlangsung secara online. Penggunaan media sosial bagi anak-anak memiliki manfaat yang besar dan juga memiliki efek samping atau suatu pengaruh yang negatif juga. Manfaat mengggunakan media sosial banyak sekali, diantaranya menambah wawasan atau ilmu lebih banyak, menambah banyak teman, memudahkan dalam berkomunikasi. Sedangkan pengaruh negatif media sosial bagi anak-anak adalah memiliki efek kecanduan bermain media sosial melalui alat berupa HP. Sehingga dapat menimbulkan sifat malas dalam melakukan kegiatan yang lainnya. Oleh karena itu sebelum melakukan pendidikan online guru harus terlebih dahulu untuk berkomunikasi dan membina orang tua siswa dengan baik karena orang tua memiliki peran yang sangat besar dalam proses belajar mengajar online, guru dituntut untuk bekerja ekstra agar siswa yang dibimbing tidak mengalami kebingungan dan mendapatkan tekanan mental saat belajar, karena anak MI memiliki otak yang sensitif dalam berfikir, jika kita sebagai pendidik tidak benar dalam mengambil keputusan bisa saja membuat anak didik kita menjadi stres dan kebingungan.

\section{RESEARCH METHOD}

Penelitian ini dimaksudkan untuk mengetahui bagaimana pengaruh pandemi covid-19 dalam kegiatan belajar mengaja SD/MI sebagai media pembelajaran diera pandemi covid-19. Jenis penelitian yang dipilih dalam penelitian ini adalah penelitian kualitatif dengan pendekatan yang digunakan adalah deskriptif kualitatif, dengan tujuan untuk mendeskripsikan dan menganalisis fenomena, peristiwa, aktivitas sosial, sikap, kepercayaan, presepsi, pemikiran orang sekitar secara individual maupun kelompok. Penelitian kualitatif adalah penelitian yang bersifat deskriptif dan cenderung mengunakan analisis. Kriyantono menyatakan bahwa, "Riset kualitatif bertujuan untuk menjelaskan fenomena dengan sedalam-dalamnya melalui pengumpulan data sedalam-dalamnya". Sehingga dalam penelitian ini, peniliti bertujuan untuk menggambarkan, mengungkapkan, dan menjelaskan pengaruh media sosial bagi anak usia SD/MI sebagai media pembelajaran diera pandemi covid-19. Penelitian ini dilaksanakan di rumah masing-masing penulis tepatnya di Bojonegoro, 
Lamongan, Sidoarjo, dan Surabaya dengan mengamati adik yang masih sekolah SD/MI. Penelitian dilakukan pada tanggal 17 Maret 2020 s.d. 18 April 2020.

Pengumpulan data pada penelitian ini menggunakan tiga metode, yaitu dengan cara wawancara, observasi, dan dokumentasi. Metode wawancara digunakan untuk mendapatkan data ataupun informasi yang dibutuhkan. Metode observasi digunakan untuk memperoleh data-data deskriptif. Dan metode dokumentasi digunakan untuk mendukung kebenaran data yang telah diperoleh. Teknik analisis data yang digunakan dalam penelitian ini adalah Triangulasi.

\section{RESULTS AND DISCUSSION}

Hasil penelitian ini diambil dari mengamati kegiatan pembelajaran secara online yang dilakukan anak usia SD/MI pada masa pandemi covid-19. Berdasarkan pengamatan didapatkan jawaban-jawaban dan masalah yang muncul. Adanya peraturan WFH (work from home) sehingga semua kegiatan diliburkan, hampir semua kegiatan hanya dapat dilakukan yakni dengan jalan media sosial, kondisi sebelum terjadinya covid-19 yang berlangsung secara beratatap muka, menjadi suatu kegiatan yang dilarang, tentu saja hal ini membuat muncul ke-ego-an dalam diri masing-masing. Seperti diliburkannya pekerjaan, sehingga perekonomian menjadi menurun. Begitu juga dengan kegiatan pembelajaran yang di sekolah, yang sebelumnya berlangsung di sekolah atau lembaga, menjadi berlangsung secara online guna mencegah terjadinya penularan pada masa pandemi ini. Penelitian pembelajaran secara online di daerah Sidoarjo dan Surabaya dapat belangsung dengan baik, peserta didik dapat menggunakan berbagai aplikasi seperti google classroom, google meet, edmodo, tontonan video materi dari guru, whatsApp dan berbagai aplikasi soal seperti quipper, . quizizz, quizlet dan berbagai aplikasi yang lainnya. Sedangkan kegiatan pembelajaran di desa tentu saja sangat sulit mendapatkan jaringan internet, penelitian pembelajaran online di daerah Bojonegoro dan Lamongan belum sepenuhnya secara online, peserta didik diminta untuk belajar di rumah di dampingi orangtua, dan guru memberi perintah melalui whatsApp wali murid.
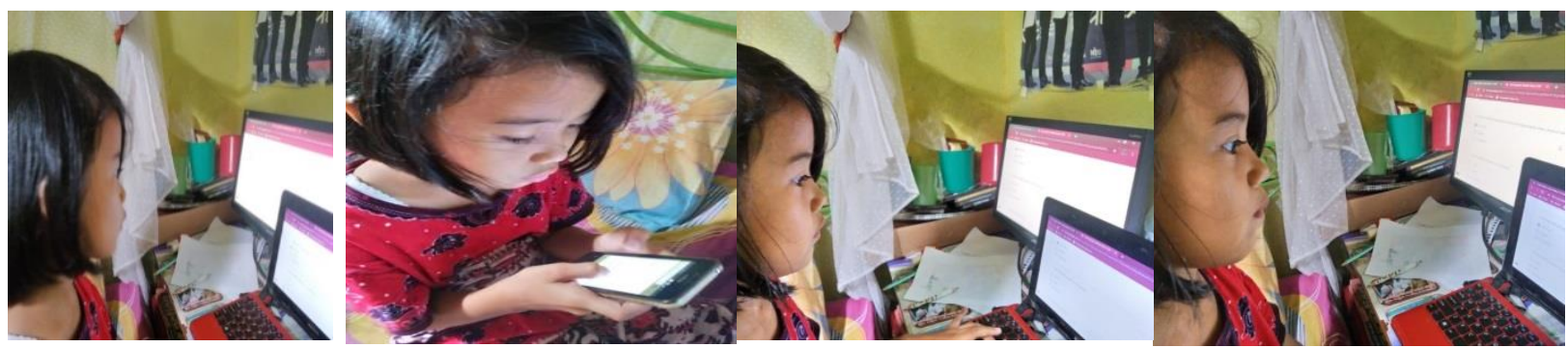

Gambar 1: Kegiatan Siswa di Rumah saat Mengerjakan Tugas

Sebagai pendidik menjadi sebuah tuntutan untuk menguasai bidang IT secara mendadak, demi tetap berlangsungnya kegiatan pembelajaran. Dari penelitian pendidik di daerah Sidoarjo dan Surabaya, para pendidik sangat mencari berbagai cara yang efisien untuk melakukan kegiatan pembelajaran, pendidik melakukan pembelajaran secara matang mulai dari belajar media aplikasi yang akan digunakan, membuat video materi yang akan disampaikan, dengan mempertimbangkan ekonomi, 
hingga mencari aplikasi yang dapat diterima untuk pembelajaran namun tidak memakan banyak kuota.

Kegiatan belajar mengajar untuk anak SD/MI secara daring atau online sebagai media pembelajaran diera pandemi covid-19 memiliki sisi baik atau keuntungan dan ada pula sisi buruk atau kerugiannya. Pengaruh positif dari pandemi covid-19 dalam KMB SD/MI diantaranya yaitu Anak dapat mendalami teknologi sejak usia dini, pembelajaran lebih fleksibel dapat dilakukan dimana saja dengan menggunakan sistem daring, dapat menghemat pengeluaran transportasi, materi dapat disave dan diputar ulang jika kurang dipahami, anak dapat menggali pengetahuan dan sumber informasi secara luas. Dan adapun pengaruh negatif dari pandemi covid-19 dalam KMB SD/MI diantaranya yaitu Kurang efektifnya sistem belajar mengajar, anak lebih sulit dalam memahami, dapat menimbulkan sifat kecanduan bermain media sosial, sehingga timbul ketergantungan tidak bisa jauh dari gadget terutama $\mathrm{HP}$, sehingga terjadi kegiatan anak yang selalu mengutamakan $\mathrm{HP}$, seperti mau makan pegang $\mathrm{HP}$, mau tidur pegang $\mathrm{HP}$, dan bagun tidur pegang $\mathrm{HP}$, selain itu guru tidak dapat mengawasi peserta didik secara langsung, walaupun di rumah pembelajaran bersama orangtua, namun peran guru sebagai pendidik tetap harus bertanggung jawab, banyak mengeluarkan uang untuk keperluan kuota internet, tidak semua anak dan orang tua dapat mengikuti perkembangan media sosial, anak memiliki kesempatan bermain gadget lebih lama, guru sering memberi tugas namun tidak memberi materi, Berdampak pada kesehatan mata, dan tubuh yang kurang bergerak, timbulnya sikap anti sosial, dan adanya gambar atau iklan yang muncul berbau pornografi.

Pada pembelajaran daring timbullah sikap anti sosial anak akibat asyiknya anak bermain gadget, banyak perubahan sikap anti sosial yang timbul, ketika anak mendapat seruan dari orang tua ia lebih mementingkan dirinya sendiri bermain di dunia maya. Tingkat kerajinan anak menjadi menurun seperti bagun lebih siang. Namun dari pembelajaran daring, anak dapat lebih dekat dengan keluarga, pendidikan berlangsung informal bersama keluarga, menjadi cara efektif penanaman moral anak, seperti memperkuat moral keagamaan anak, selain itu anak dapat pandai menggali informasi dan lebih rajin membaca baik membaca buku, maupun membaca berbagai macam berita.

\section{CONCLUSIONS}

Dengan demikian dapat kita lihat dampak positif dan negatif dari pembelajaran online yang diterapkan oleh setiap sekolah dalam menghadapi virus Corona tersebut, dalam kegiatan belajar mengajar (KMB) secara online sendiri memiliki efek yang bagus terhadap pembelajaran, terutama pembelajaran anak SD/MI, karena anak bisa mengenal dan belajar lewat online dan dapat memanfaatkan teknologi yang ada secara bijak dan lebih mengetahui bagaimana tata cara yang baik dalam menggunakan gadget atau media elektronik yang dapat membantu dalam pembelajaran online yang lainnya.

Tetapi disamping dampak baik tersebut memiliki dampak negatif yang lebih besar karena kegiatan belajar mengajar sendiri lebih baik dilakukan secara langsung bertatap muka dengan guru atau pendidik karena pembelajaran online tidak bisa menanamkan pendidikan yang berkarakter sosial serta pendidikan secara online juga dapat menimbulkan jiwa anti sosial karena membuat anak anak menjadi nyaman 
dengan dunianya sendiri dan acuh dengan keadaan sekitar, oleh sebab itu peran orang tua sangatlah penting dalam hal ini, orang tua harus dapat mengawasi anak dengan baik dalam terjadinya proses pembelajaran online karena anak usia SD/MI sendiri yang masih labil dan masih sangat membutuhkan adanya bimbingan dalam menjalankan pembelajaran berbasis online agar tidak terjadi sesuatu hal yang tidak diinginkan.

\section{ACKNOWLEDGEMENTS}

Peneliti mengucapkan terima kasih kepada PGMI FT IAI Al Khoziny Sidoarjo dan PGMI FTK UINSA Surabaya atas dukungan dan bantuan dalam hasil penelitian ini.

\section{REFERENCES}

Ahmad Jaelani, Hamdan Fauzi, Hety Aisah, Q. Y. Z. (2020). PENGGUNAAN MEDIA ONLINE DALAM PROSES KEGIATAN BELAJAR MENGAJAR PAI DIMASA PANDEMI COVID-19 (Studi Pustaka dan Observasi Online). JURNAL IKA: $\begin{array}{llll}\text { IKATAN ALUMNI PGSD UNARS, } & \text { 8(1), }\end{array}$ https://doi.org/10.1017/CBO9781107415324.004

Amalina. (2021). Jurnal Obsesi: Jurnal Pendidikan Anak Usia Dini Pembelajaran Matematika Anak Usia Dini di Masa Pandemi Covid-19 Tahun 2020 Abstrak. Jurnal Obsesi: Jurnal Pendidikan Anak Usia Dini, 5(1), 538-548. https://doi.org/10.31004/obsesi.v5i1.592

Aryulina, D. (2006). Biologi 1 SMA dan MA untuk Kelas X. Jakarta: Erlangga.

Firman, F. (2020). Dampak Covid-19 terhadap Pembelajaran di Perguruan Tinggi. BIOMA: Jurnal Biologi Dan Pembelajarannya, 2(1), 14-20. Retrieved from https://ojs.unsulbar.ac.id/index.php/bioma/article/view/743

Herliandry, L. D., Nurhasanah, Suban, M. E., \& Heru, K. (2020). Transformasi Media Pembelajaran Pada Masa Pandemi Covid-19. Jurnal Teknologi Pendidikan, 22(1), 6570. https://doi.org/https://doi.org/10. 21009/jtp.v22i1.15286

Harususilo, Y. E. (2020). Work From Home "mengajar dari rumah".

Khasanah, D. R. A. U., Pramudibyanto, H., \& Widuroyekti, B. (2020). Pendidikan Dalam Masa Pandemi Covid-19. Jurnal Sinestesia, 10(1), 41-48. Retrieved from https:// sinestesia.pustaka.my.id/journal/article/view/44

Pakpahan, R., \& Fitriani, Y. (2020). ANALISA PEMANFAATAN TEKNOLOGI INFORMASI DALAM PEMBELAJARAN JARAK JAUH DI TENGAH PANDEMI VIRUS CORONA COVID-19. JISAMAR (Journal of Information System, Applied, Management, Accounting and Researh, 4(2), 30-36.

Permana, E. P. (2018). Pengaruh Media Sosial sebagai Sumber Belajar IPS TerhadapMotivasi Belajar, Kemampuan Berpikir Kritis dan Berpikir Kreatif Siswa Sekolah Dasar. PINUS, 54-59.

Putranti, N. (2013). Cara Membuat Media Pembelajaran Online Menggunakan Edmodo. pendidikan tekonologi dan sains, 139-147.

Robert J. Glass, L. M. (2006). Targeted Social Distancing Designs for Pandemic Influenza. Sindang, E. (2013). Manfaat Media Sosial dalam Ranah Pendidikan dan Pelatihan. Pusdiklat KNPK. Jakarta.

Setyorini, I. (2020). Pandemi Covid-19 Dan Online Learning: Apakah Berpengaruh Terhadap Proses Pembelajaran Pada Kurukulum 13. Journal of Industrial Engineering 
\& Management Research ( JIEMAR ), 01(Juni), 95-102.

Taseman. (2020). Pemanfaatan Media Visual Pada Pembelajaran IPS Di MI Darul Mutaallimin Sidoarjo. BADA'A: Jurnal Ilmiah Pendidikan Dasar, 2(1), 86-97.

Tosepu, Y. A. (2018). Media Baru dalam Komunikasi Politik di Dunia Virtual. Surabaya: CV. Jakad Publishing Surabaya .

Yuhefizar. (2008). 10 Jam Menguasai Internet Teknologi dan Aplikasi. Jakarta: PT Elex Media Komputindo.

Wiryanto. (2020). PROSES PEMBELAJARAN MATEMATIKA DI SEKOLAH DASAR DI TENGAH PANDEMI COVID-19 Wiryanto Universitas Negeri Surabaya. Jurnal Review Pendidikan Dasar, Kajian Pendidikan Dan Hasil Pendidikan, Universitas Negeri Surabaya, 6(2).

Author (s) :

*A Risalah (Corresponding Author)

Department of Faculty Education,

Institute University of Islamic Al Khoziny Sidoarjo, Indonesia

Jl. KH. Khamdani, Siwalan Panji Buduran, Sidoarjo 61252, Indonesia

Email: ainurrisalah.relawanpenggerak@gmail.com

\section{W Ibad}

Department of Faculty Education,

Institute University of Islamic Al Khoziny Sidoarjo, Indonesia

Jl. KH. Khamdani, Siwalan Panji Buduran, Sidoarjo 61252, Indonesia

Email: Ibad280590@gmail.com

\section{Maghfiroh}

Department of Faculty Teacher and Education,

Islamic State University of Sunan Ampel, Surabaya, Indonesia

Jl. Ahmad Yani 117, Surabaya, East Java, 60237, Indonesia

Email: $\underline{\text { m4ghfiroh@gmail.com }}$

\section{I Azza}

Department of Faculty Teacher and Education, Islamic State University of Sunan Ampel, Surabaya, Indonesia Jl. Ahmad Yani 117, Surabaya, East Java, 60237, Indonesia Email: ishomuddinazza@gmail.com

\section{S A Cahyani}

Department of Faculty Teacher and Education,

Islamic State University of Sunan Ampel, Surabaya, Indonesia

Jl. Ahmad Yani 117, Surabaya, East Java, 60237, Indonesia

Email: percybgn@gmail.com

\section{Z A Ulfayati}

Department of Faculty Teacher and Education,

Islamic State University of Sunan Ampel, Surabaya, Indonesia

Jl. Ahmad Yani 117, Surabaya, East Java, 60237, Indonesia

Email: aliyazhrt03@gmail.com 